\title{
Article \\ On the Authorship, Availability, and Improper Use of Sus scrofa ferus for Referring to Wild Pigs
}

\author{
Alessio Iannucci
}

check for

updates

Citation: Iannucci, A. On the Authorship, Availability, and Improper Use of Sus scrofa ferus for Referring to Wild Pigs. Taxonomy 2022, 2, 91-98. https://doi.org/ 10.3390/taxonomy2010007

Academic Editor: Edgar Lehr

Received: 31 December 2021

Accepted: 3 February 2022

Published: 7 February 2022

Publisher's Note: MDPI stays neutral with regard to jurisdictional claims in published maps and institutional affiliations.

Copyright: (C) 2022 by the author. Licensee MDPI, Basel, Switzerland. This article is an open access article distributed under the terms and conditions of the Creative Commons Attribution (CC BY) license (https:// creativecommons.org/licenses/by/ $4.0 /)$.
Department of Earth Sciences, Sapienza University of Rome, PaleoFactory, P.le Aldo Moro 5, 00185 Rome, Italy; alessio.iannucci@uniroma1.it

\begin{abstract}
The wild boar, Sus scrofa, is one of the most successful large mammals in terms of geographic distribution. Along with its domestic descendant, the pig, they are extremely important animals for conservation, economy, human sustenance, and well-being. Naming wild and domestic pigs in a way that allows them to be distinguished effectively and unambiguously is crucial for a number of studies in archaeozoology, biomedicine, genetics, epidemiology, paleontology, and wildlife management. Sus scrofa ferus, or less commonly, Sus ferus, is often used to refer to wild populations, frequently in opposition to $S$. scrofa domesticus, or S. domesticus in reference to domestic pigs. Here, it is argued that $S$. scrofa ferus is available for nomenclatural purposes but should not be regarded as valid from a taxonomic perspective. Authors should refer wild populations to valid subspecies, e.g., S. scrofa scrofa, or to S. scrofa ssp., when information on the subspecific status is not available or relevant for the research questions under consideration. This remark is not a mere nomenclatural clarification, because the potential identification of differences between wild boar taxa is often hidden behind a simplistic dichotomy between wild and domestic forms.
\end{abstract}

Keywords: nomenclature; taxonomy; Suidae; Artiodactyla; Mammalia; domestication; wild boar; nomen protectum; nomen oblitum; reversal of precedence

\section{Introduction}

Suids (Suidae, Artiodactyla, Mammalia), or simply pigs, comprise about twenty extant species [1,2]. The wild boar, Sus scrofa Linnaeus, 1758 [3], stands out as the most widely distributed wild pig, natively present in most of Eurasia and North Africa and introduced in all continents apart from Antarctica [4]. Wild boars are characterized by an extremely high reproductive rate in comparison to other artiodactyls of similar body mass, which exacerbates their impact on conservation and the economy, as well as explaining their evolutionary success [5-7].

The domestic pig, derived from the wild boar, is also an enormously important animal for human subsistence and welfare, being the only domesticated omnivore among major livestock species [8]. This relationship goes back several millennia, meaning that the correct identification of pig remains (wild or domestic) is a crucial archeozoological question $[9,10]$.

Naming wild and domestic pigs in a way that allows them to be distinguished effectively and unambiguously is crucial for addressing several research questions. There is a widespread approach in referring to wild boar populations as Sus scrofa ferus or less frequently as Sus ferus, as opposed to domestic pigs, named S. scrofa domesticus or S. domesticus. Here, it is argued that $S$. scrofa ferus is available for nomenclatural purposes but should not be regarded as valid from a taxonomic perspective, also clarifying the authorship of the taxon and providing a concise review of the development of this concept. 


\section{The Problem of Naming Domestic Species}

Scientific names based on domestic animals fall within the scope of the International Code of Zoological Nomenclature (hereafter, the Code [11]), but they are not accompanied by particular recommendations. Many wild ancestral species and their domestic relatives share the same Latin name, but in some cases, wild and domestic forms are denoted by traditionally separated epithets [12]. Basically, some domestic animals differ substantially from their wild progenitors to the extent that is often desirable and hence common practice to refer to them with distinct names, but in the absence of specific guidelines in the Code, a variety of approaches have been proposed.

This has long engendered nomenclatural instability [12-15]. Different proposals for naming domestic animals included, among others, referring to them solely by using vernacular names, as a consequence of the application for excluding names based on domestic animals from zoological nomenclature [13]; the adoption of an infrasubspecific distinction of domestic species, mediated by the word "forma" (f.), e.g., Canis lupus f. familiaris for referring to the dog [16,17]; the apposition of "familiaris" after the species name, e.g., C. lupus "familiaris" [18,19]; using a single Latin word in capitals and italics, such as CANIS or SUS [20]. Eventually, a relatively recent ruling of the International Commission on Zoological Nomenclature (ICZN) conserved the widespread usage of 17 specific names based on wild species, which were coined at the same time or later than those available for their domestic counterparts [21]. This ruling does not regulate whether to include a wild ancestor and its domestic descendant in the same species or to separate them into different species and/or subspecies-nor should it, in compliance with the principle of taxonomic freedom endorsed by the Code- but it is indeed advisable to adopt separate names for domestic animals [12].

\section{The Case of Sus scrofa ferus}

Whilst in most cases names available for domestic animals predate or are a contemporary of those used for their wild relatives, S. scrofa was considered an exception, with S. domesticus Erxleben, 1777 [22], only named later [12]. The epithet ferus means "wild", and it has been often employed for designating wild forms of domestic animals, for instance, Equus ferus Boddaert, 1785 [23], in place of Equus caballus Linnaeus, 1758. Referring to the wild boar as "ferus" has a long history, as it is, for instance, present in Pliny the Elder's Naturalis Historia [24]. However, discussing the nomenclatural availability and taxonomic validity of S. scrofa ferus is not a straightforward task. Sus scrofa ferus was first used as a valid taxon (as requested in Art. 11.5 of the Code for being considered available) in the first part of the thirteenth edition of the Systema Naturae, curated by Gmelin and published in 1788, ten years after Linnaeus' death. (Figure 1) [25]. In those few cases where the authorship of S. scrofa ferus is credited, it is indeed attributed to Gmelin, 1788 [26,27]. 
A

MAMMALIA BESTIÆ. Sus.

IV. BESTIA.

Dentes Primores utrinque: intermediis difantibus.

Laniarï femper uno plures utrinque:

Nafus ultra os prominens.

16. SUS. Dentes Primores Superiores IV, convergentes.

Inferiores VIII patuli.

Laniarï Superiores II breviores.

Inferiores II exferti.

Scrofa. I. S. dorfo antice fetofo, cauda pilofa. Fn.fvec. 36. Syft. nat. $\mathrm{I} 2$.

B

\section{I9. S V S.}

Dentes Primores Supperiores IV conuergentes.

Inferiores VI prominentes.

(Variante pauiluliwn numero in variis.)

Laniarii Stuperiores II breuiores.

Inferiores II exferti.

Roftrum truncatum, prominens, mobile. Pedes bifulci.

Scrofa. I. S. dorfo antice fetofo, cauda pilofa.

Aper. a, Ferus. (Vna cum fynonymis totius fpeciei.)

\section{C}

$$
\text { MAMMALIA BELLUAE. Sus? }
$$

35. SUS. Dentes primores fuperiores IV' convergentes. inferiores (plerisque) VI prominentes.

laniarii fuperiores II breviores. inferiores II exferti. Roftrum truncatum, prominens, mobile. Pedes (utplurimum) bifulci.

Serofa, I. S. dorfo antice fetofo, cauda pilofa. Fn. Juec, 2r. Amoen. ac. V. p. $46 \mathrm{r}$,

ferus. $\quad$. S. caudatus auriculis brevibus fubrotundis, cauda pilofa.

Figure 1. Extract of Linnaeus' description of Sus in the tenth edition of the Systema Naturae (A), extract of Erxleben's description of Sus in the Systema Regni Animalis (B), and extract of Gmelin's description of Sus in the thirteenth edition of the Systema Naturae (C). 
However, according to Art. 11.6.1, if a name published as a junior synonym had been treated before 1961 as an available name and either adopted as the name of a taxon or treated as a senior homonym, it is thus made available but dates from its first publication as a synonym [11]. This case applies here, because Erxleben [22] had already published S. scrofa ferus within the synonymy of its newly named S. scrofa aper. Therefore, Gmelin's validation of the taxon satisfies the provisions of Art. 11.6.1 for making S. scrofa ferus Erxleben, 1777, available (see also Art. 50.7 for remarks on the authorship).

In any case, it could be argued that $S$. scrofa aper has priority over S. scrofa ferus. Even though this is undeniable, it is also true that $S$. aper or $S$. scrofa aper never gained widespread usage. This is perhaps because "aper" — which in Latin basically means "wild boar" - was also applied to many different suid taxa (especially but not only in pre-Linnean taxonomy, see, e.g., the synonymy lists in Gmelin [25]). For example, as a genus in Aper aethiopicus Pallas, 1766 [28], in which instance the name was suppressed under the plenary powers by the ICZN, for the purposes of the principle of priority but not for those of the principle of homonymy [29]. The same epithet can of course be used at different taxonomic ranks without this being in violation of the principle of homonymy, but the case of the desert warthog testifies to another example of a seldom used "aper", which was eventually replaced by another name (i.e., Phacochoerus). It is possible that Gmelin's choice of replacing $S$. scrofa aper with $S$. scrofa ferus was partly due to the intention to provide a name of a less equivocal application, despite being in violation of the principle of priority as currently recognized.

Nevertheless, the provisions of the principle of priority are moderated in cases where a strict adherence to it would be detrimental for stability. A quick search on Google Scholar for "Sus scrofa ferus" yielded more than 1180 results (on 22 January 2022), but no recent mention for "Sus scrofa aper", providing an indication of the widespread usage of S. scrofa ferus as a valid taxon. In a more formal way and with specific reference to Art. 23.9 of the Code, which regulates the admissible cases for reversal of priority, I observe that: (1) to the best of my knowledge, $S$. aper or S. scrofa aper have seldom been used and never after 1899 (Art. 23.9.1.1), if not merely under the conditions of Art. 23.9.6; (2) S. scrofa ferus has been widely adopted, including its usage as a presumed valid name in at least 25 works, published by at least 10 authors in the last 50 years and encompassing a span of not less than 10 years (e.g., Figure 2, [30-63]) (Art. 23.9.1.2). Therefore, the necessary conditions listed under Art. 23.9 for maintaining prevailing usage of $S$. scrofa ferus instead of $S$. scrofa aper by reversal of precedence without a formal ruling of the ICZN are met [11]. Following this nomenclatural act, $S$. scrofa ferus becomes a nomen protectum, while S. scrofa aper is now a nomen oblitum.

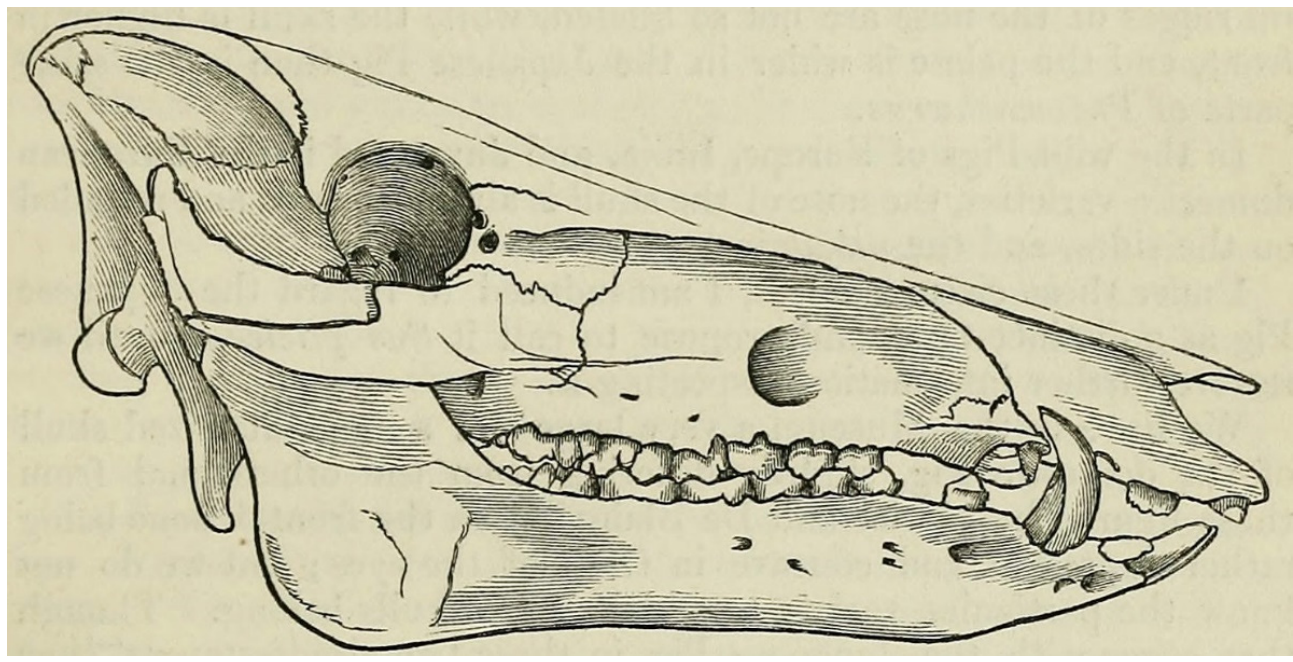

Figure 2. Depiction of a wild boar skull labelled Sus scrofa ferus. Modified from Gray [32]. 


\section{Discussion}

After Gmelin's adoption of S. scrofa ferus for denoting the wild boar in the thirteenth edition of the Systema Naturae [25], the usage of the name became widespread [30-33]. However, although S. scrofa ferus Erxleben, 1777, is available for nomenclatural purposes, it should not be regarded as valid from a taxonomic perspective, as treating the wild boar as a single entity is a reductive and arguably undesirable approach in many fields of research $[1,4]$. Sus scrofa is a widely distributed species with several recognized subspecies, and there are proposals to raise many of them to full species [1,4]. While the validation of these proposals needs further efforts, and the delimitation of boundaries between recognized taxa is challenging, avoiding referring to wild boars simply as S. scrofa ferus would likely facilitate gathering further data and knowledge on the differences within the species.

Indeed, changing the scale of analysis often provides new insights into long-standing issues. For instance, it has long been hypothesized that the wild boar underwent a dimensional change from large- to small-sized forms during the Pleistocene, eventually reaching the size of extant populations [64-67]. Testing this observation necessitates geographically constrained settings, because the extant populations vary markedly in size, encompassing the entire fossil record of the taxon [68,69]. When this has been properly taken into account, resulting analyses have revealed more complex evolutionary scenarios than the simple dimensional trend suggested by previous research conducted at a coarser geographic scale $[7,70]$.

Sus scrofa was not included in the previously mentioned application to the ICZN for preserving the usage of several names adopted for wild progenitors whose establishment postdate or is a contemporary of that of their domestic derivatives [21], as it was considered that S. scrofa Linnaeus, 1758, for the wild boar predates S. domesticus Erxleben, 1777 [12]. However, Linnaeus' concept of $S$. scrofa encompassed both wild and domestic pigs [3], and separate names that are available according to the Code were both established by Erxleben [22]. For maintaining prevailing usage and ensuring consistency and stability, it is argued here to continue referring to the wild boar as S. scrofa and the domestic pig as $S$. domesticus. Authors should maintain the taxonomic freedom to decide whether to include the domestic pig in the wild species concept (e.g., S. scrofa domesticus), while using S. scrofa ferus should be avoided. Following this approach, S. scrofa ferus falls in synonymy with the nominotypical S. scrofa scrofa [26]. Authors should refer wild populations to valid subspecies-e.g., S. scrofa scrofa-or to S. scrofa ssp., when information on the subspecific status is not available or relevant for the research questions under consideration.

Nevertheless, it could be argued that referring to the domestic pig as a single taxonomic entity is inconsistent as well. In fact, the domestication of the pig occurred independently at least twice, in the Near East and East Asia [71-76]. As a result, S. domesticus as commonly conceived is polyphyletic, implying that the descendants of the two domestication processes should be placed in different taxa. On the other hand, an effective allocation to one group or the other would often be difficult, generating confusion instead of promoting clarity and stability. Therefore, at least for the moment it is advisable to continue pragmatically to refer the domestic pig to a single taxon. Moreover, although the case for an independent domestication of the pig is the most supported by zooarchaeological and genetic evidence $[73,76]$, it is likely that other domestic mammals have multiple origins as well [77].

Finally, even the use of vernacular names is a source of great ambiguity. For instance, "wild pigs" is often used in a systematic sense to refer to all wild species of Suidae, but also to domestic pigs returned to a wild state [2]. Pigs are extremely important animals to humans, which partly explains why there are many ways to refer to them (e.g., (wild) boar, hog, and swine). These terms are today used sometimes interchangeably or in other cases with a particular meaning, partly but not only depending on the common practice of different research fields. A cohesive nomenclatural solution would thus require a collective 
effort. For the time being, in studies, documents, and reports in which confusion may arise, it would be appropriate to include a concise explanation of the nomenclature adopted.

Funding: This research received no external funding.

Data Availability Statement: Not applicable.

Acknowledgments: I would like to thank L. Zou for the invitation to prepare this work. This paper benefitted from the comments and suggestions of three anonymous reviewers, for which I am grateful. I thankfully acknowledge the use of the free repositories Biodiversity Heritage Library (http:/ / www.biodiversitylibrary.org/, accessed on 1 February 2022) and Internet Archive (http:/ / archive.org/, accessed on 1 February 2022).

Conflicts of Interest: The author declares no conflict of interest.

\section{References}

1. Groves, C.P.; Grubb, P. Ungulate Taxonomy; Johns Hopkins University Press: Baltimore, MD, USA, 2011.

2. Melletti, M.; Meijaard, E. Ecology, Conservation and Management of Wild Pigs and Peccaries; Cambridge University Press: Cambridge, UK, 2017.

3. Linnaeus, C. Systema Naturae per Regna Tria Naturae, Secundum Classes, Ordines, Genera, Species, Cum Characteribus, Differentiis, Synonymis, Locis. tomus I, 10th ed.; Laurentii Salvii: Stockolm, Sweden, 1758.

4. Keuling, O.; Podgórski, T.; Monaco, A.; Melletti, M.; Merta, D.; Albrycht, M.; Genov, P.V.; Gethöffer, F.; Vetter, S.G.; Jori, F.; et al. Eurasian Wild Boar Sus scrofa (Linnaeus, 1758). In Ecology, Conservation and Management of Wild Pigs and Peccaries; Melletti, M., Meijaard, E., Eds.; Cambridge University Press: Cambridge, UK, 2017; pp. 202-233.

5. Bieber, C.; Ruf, T. Population dynamics in wild boar Sus scrofa: Ecology, elasticity of growth rate and implications for the management of pulsed resource consumers. J. Appl. Ecol. 2005, 42, 1203-1213. [CrossRef]

6. Barrios-Garcia, M.N.; Ballari, S.A. Impact of wild boar (Sus scrofa) in its introduced and native range: A review. Biol. Invasions 2012, 14, 2283-2300. [CrossRef]

7. Iannucci, A.; Sardella, R.; Strani, F.; Mecozzi, B. Size shifts in late Middle Pleistocene to Early Holocene Sus scrofa (Suidae, Mammalia) from Apulia (southern Italy): Ecomorphological adaptations? Hystrix 2020, 31, 10-20.

8. Clutton-Brock, J. A Natural History of Domesticated Mammals, 2nd ed.; Cambridge University Press: Cambridge, UK, 1999.

9. Albarella, U.; Dobney, K.; Ervynck, A.; Rowley-Conwy, P. Pigs and Humans: 10,000 Years of Interaction; Oxford University Press: Oxford, NY, USA, 2007.

10. Rowley-Conwy, P.; Albarella, U.; Dobney, K. Distinguishing wild boar from domestic pigs in prehistory: A review of approaches and recent results. J. World Prehist. 2012, 25, 1-44. [CrossRef]

11. International Commission on Zoological Nomenclature. International Code of Zoological Nomenclature, 4th ed.; The International Trust for Zoological Nomenclature: London, UK, 1999.

12. Gentry, A.; Clutton-Brock, J.; Groves, C.P. The naming of wild animal species and their domestic derivatives. J. Archaeol. Sci. 2004, 31, 645-651. [CrossRef]

13. Groves, C.P. Request for a declaration modifying Article 1 so as to exclude names proposed for domestic animals from zoological nomenclature. Bull. Zool. Nomencl. 1971, 27, 269-272. [CrossRef]

14. Groves, C.P. On the nomenclature of domestic animals. Bull. Zool. Nomencl. 1995, 52, 137-141. [CrossRef]

15. Gautier, A. Once more: The names of domestic animals. Anthropozoologica 1997, 25-26, 113-118.

16. Bohlken, H. Zur nomenklatur der haustiere. Zool. Anzeiger 1958, 160, 167-168.

17. Bohlken, H. Haustiere und zoologische systematik. Z. Tierzücht. Züchtungsbiol. 1961, 76, 107-113. [CrossRef]

18. Dennler de La Tour, G. La descendencia del perro. In Actas y Trabajos del Primer Congreso Sudamericano de Zoologia. Tomo 4, Proceedings of the Primer Congreso Sudamericano de Zoologia, La Plata, Argentina, 12-24 October 1959; Comisión de Investigaciones Científicas de la Provincia de Buenos Aires y Consejo Nacional de Investigaciones Científicas y Técnicas: La Plata, Argentina, 1960; pp. 215-223.

19. De La Tour, G.D. Zur Frage der Haustier-Nomenklatur. Säugetierkundliche Mitteilungen 1968, 16, 1-20.

20. Uerpmann, H.-P. Proposal for a separate nomenclature of domestic animals. In Skeletons in her Cupboard, Festschrift for Juliet Clutton-Brock; Oxbow Monograph 34; Clason, A.T., Payne, S., Uerpmann, H.-P., Eds.; Oxbow Books: Oxford, UK, 1993; pp. $239-241$.

21. International Commission on Zoological Nomenclature. Opinion 2027 (Case 3010). Usage of 17 specific names based on wild species which are predated by or contemporary with those based on domestic animals (Lepidoptera, Osteichthyes, Mammalia): Conserved. Bull. Zool. Nomencl. 2003, 60, 81-84.

22. Erxleben, J.C.P. Systema Regni Animalis per Classes, Ordines, Genera, Species, Varietates, Cum Synonymia et Historia Animalium. Classis 1: Mammalia; Weygandianis: Leipzig, Germany, 1777.

23. Boddaert, P. Elenchus Animalium, Volumen 1 (Sistens Quadrupedia); C.R. Hake: Rotterdam, The Netherlands, 1785.

24. Naturalis Historia. Available online: https://la.wikisource.org/wiki/Naturalis_Historia (accessed on 20 December 2021). 
25. Gmelin, J.F. Caroli a Linné. Systema Naturae per Regna Tria Naturae, Secundum Classes, Ordines, Genera, Species, Cum Characteribus, Differentiis, Synonymis, Locis, 13th ed.; Impensis Georg. Emanuel Beer: Leipzig, Germany, 1788.

26. Wilson, D.E.; Reader, D.M. Mammal Species of the World. A Taxonomic and Geographic Reference, 3rd ed.; John Hopkins University Press: Baltimore, MD, USA, 2005.

27. Mayer, J.J.; Brisbin, I.L. Wild Pigs in the United States: Their History, Comparative Morphology, and Current Status, paperback ed.; University of Georgia Press: Athens, GA, USA, 2008.

28. Pallas, P.S. Miscellanea Zoologica Quibus Novae Imprimis Atque Obscurae Animalium Species Describuntur et Observationibus Iconibusque Illustrantur; P. van Cleef: The Hague, The Netherlands, 1766.

29. Melville, R.V.; Smith, J.D. Official Lists and Indexes of Names and Works in Zoology; The International Trust for Zoological Nomenclature: London, UK, 1987.

30. Fischer, G. Ueber die Verschiedene Form des Intermaxillarknochens in Verschiedenen Thieren; Schäferschen Buchhandlung: Leipzig, Germany, 1800 .

31. Rütimeyer, L. Die Fauna der Pfahlbauten in der Schweiz; Verlag von Banhmaier's Buchhandlung: Basel, Switzerland, 1861.

32. Gray, J.E. On the skull of the Japanese pig (Sus pliciceps). Proc. Zool. Soc. Lond. 1862, 30, 13-17. [CrossRef]

33. Rolleston, G., XIII. On the domestic pig of prehistoric times in Britain, and on the mutual relations of this variety of pig and Sus scrofa ferus, Sus cristatus, Sus andamanensis, and Sus barbatus. Trans. Linn. Soc. Lond. 2 Zool. 1877, 1, 251-286. [CrossRef]

34. Popescu, C.P.; Quéré, J.P.; Franceschi, P.; Boscher, J. Observations chromosomiques chez le sanglier français (Sus scrofa scrofa). Annales de Génétique et de Sélection Animale 1980, 12, 395-400. [CrossRef]

35. Bonfiglio, L. Prima campagna di scavo dei depositi a mammiferi pleistocenici dell'area della grotta di S. Teodoro (Acquedolci, Messina-Sicilia). Geol. Romana 1983, 22, 271-285.

36. Zapfe, H. Die Fauna der miozänen Spaltenfüllung von Neudorf an der March (CSSR). Suidae. Österreichische Akademie der Wissenschaften, Mathematisch-Naturwissenchaft Klasse 1983, 192, 167-182.

37. Sysa, P.S.; Slawomirski, J.; Gromadzka, J. The cytogenetics of hybrids of wild pig (Sus scrofa ferus) with the domestic pig (Sus scrofa domestica). Polskie Archivum Weterynaryjne 1984, 24, 89-95.

38. Hartl, G.B.; Csaikl, F. Genetic variability and differentiation in wild boars (Sus scrofa ferus L.): Comparison of isolated populations. J. Mammal. 1987, 68, 119-125. [CrossRef]

39. Hraste, A.; Kantura, V.G.; Jakovac, M.; Brestovec, V.J. Morphological investigations of the glandulae profundae plicae semilunares conjuctivae in the domestic swine (Sus scrofa domesticus) and the wild hog (Sus scrofa ferus). Anat. Histol. Embryol. 1995, 24, 223-226. [CrossRef]

40. Perez, J.; Astorga, R.; Carrasco, L.; Mendez, A.; Perea, A.; Sierra, M.A. Outbreak of salmonellosis in farmed European wild boars (Sus scrofa ferus). Vet. Rec. 1999, 145, 464-465. [CrossRef]

41. Pérez-Martín, J.E.; Serrano, F.J.; Reina, D.; Mora, J.A.; Navarrete, I. Sylvatic trichinellosis in southwestern Spain. J. Wildlife Dis. 2000, 36, 531-534. [CrossRef]

42. Rowley-Conwy, P. Determination of season of death in European wild boar (Sus scrofa ferus): A preliminary study. In Archaeological Sciences 1997, Proceedings of the Conference Held at the University of Durham, 2-4 September 1997; Millard, A.R., Ed.; British Archaeological Reports International Series 939; Archaeopress: Oxford, UK, 2001; pp. 133-139.

43. Vieites, C.M.; Garriz, C.; Basso, C.P.; Bartoloni, N. Composición tisular de canales de lechones Duroc y Sus scrofa ferus x Duroc. Archiv. Zootecn. 2001, 50, 395-398.

44. Harapin, I.; Bedrica, L.; Hahn, V.; Šoštarić, B.; Gračner, D. Haematological and biochemical values in blood of wild boar (Sus scrofa ferus). Veterinarski Arhiv 2003, 73, 333-343.

45. Vieites, C.M.; Basso, C.P.; Bartolini, N. Wild boar (Sus scrofa ferus): Productivity index in an experimental outdoor farm. InVet 2003, 5, 91-95

46. Genov, P.V. Craniometric characteristics of the subgenus Sus Linnaeus, 1758 and a systematic conclusion. Galemys 2004, 16, 9-23

47. Jovanović, S.J.; Trailović, R.; Savić, M.; Sarač, M. Porcine stress syndrome (PSS) and ryanodine receptor 1 (RYR1) gene mutation in European wild pig (Sus scrota ferus). Acta Vet. Beograd 2005, 55, 251-255.

48. Bejenaru, L.; Oleniuc, C.; Stanc, S. A faunal assemblage from the Chalcolithic settlement of Poduri-Dealul Ghindaru (Bacău County). Preliminary data on subsistence patterns associated with Cucuteni-phase B level. Analele Stiintifice Univ. Al. I. Cuza Iasi 2009, 55, 223-227.

49. Matiuti, M.; Bogdan, A.T.; Crainiceanu, E.; Matiuti, C. Research regarding the hybrids resulted from the domestic pig and the wild boar. Sci. Pap. Animal Sci. Biotechnol. 2010, 43, 188-191.

50. Oroian, T.E.; Oroian, R.G.; Pasca, I.; Oroian, E.; Covrig, L. Methods of age estimation by dentition in Sus scrofa ferus sp. Bull. UASVM Animal Sci. Biotechnol. 2010, 67, 291-295.

51. Postolache, A.N.; Ionescu, O.; Lazăr, R.; Boişteanu, P.C. Quality parameters of game meat (Sus scrofa ferus) hunter in Frasin area. Lucrări Stiintifice Med. Vet. 2011, 44, 213-222.

52. Postolache, A.N.; Ciobanu, M.M.; Boisteanu, P.C. Selected biometric characteristics of wild boar (Sus scrofa Ferus) in North-East Romania. Food Sci. Technol. 2015, 72, 137-138. [CrossRef]

53. Sant'Ana, F.J.F.D.; Garcia, E.C.; Rabelo, R.E.; Ferreira, C.D.S., Jr.; Freitas Neto, A.P.D.; Verdejo, A.C.F. Intoxicação espontânea por Senna occidentalis em javalis (Sus scrofa ferus) no Estado de Goiás. Pesquisa Veterinaria Brasileira. 2011, 31, 702-706. [CrossRef] 
54. Manning, K.; Downey, S.S.; Colledge, S.; Conolly, J.; Stopp, B.; Dobney, K.; Shennan, S. The origins and spread of stock-keeping: The role of cultural and environmental influences on early Neolithic animal exploitation in Europe. Antiquity 2013, 87, 1046-1059. [CrossRef]

55. Lazar, M.; Lazar, R.; Diaconu, N.; Boisteanu, P.C. Researches regarding the characterization of the nutritional profile of wild boar (Sus scrofa ferus). Bull. UASVM Anim. Sci. Biotechnol. 2014, 71, 2. [CrossRef]

56. Oroian, I.G.; Petrescu-Mag, I.V.; Gavriloaie, C. Some brief considerations regarding the invasive potential of the wild populations of Sus scrofa ferus and Sus scrofa domesticus outside their native range. Porcine Res. 2014, 4, 23-29.

57. Botha, M.; Petrescu-Mag, I.V.; Gavriloaie, C. Rustic gene reserves for the future of breed improvement technologies: Old swine (Sus scrofa domesticus) strains and their perspectives. Porcine Res. 2016, 6, 37-56.

58. Strani, F.; DeMiguel, D.; Bona, F.; Sardella, R.; Biddittu, I.; Bruni, L.; De Castro, A.; Guadagnoli, F.; Bellucci, L. Ungulate dietary adaptations and palaeoecology of the Middle Pleistocene site of Fontana Ranuccio (Anagni, Central Italy). Palaeogeogr. Palaeoclimatol. Palaeoecol. 2018, 496, 238-247. [CrossRef]

59. Dashti, A.; Rivero-Juarez, A.; Santín, M.; López-López, P.; Caballero-Gómez, J.; Frías-Casas, M.; Köster, P.C.; Bailo, B.; CaleroBernal, R.; Briz, V.; et al. Enterocytozoon bieneusi (Microsporidia): Identification of novel genotypes and evidence of transmission between sympatric wild boars (Sus scrofa ferus) and Iberian pigs (Sus scrofa domesticus) in Southern Spain. Transbound. Emerg. Dis. 2020, 67, 2869-2880. [CrossRef]

60. Gaudreault, N.N.; Madden, D.W.; Wilson, W.C.; Trujillo, J.D.; Richt, J.A. African swine fever virus: An emerging DNA arbovirus. Front. Vet. Sci. 2020, 7, 215. [CrossRef]

61. Rivero-Juarez, A.; Dashti, A.; López-López, P.; Muadica, A.S.; Risalde, M.D.L.A.; Köster, P.C.; Machuca, I.; Bailo, B.; de Mingo, M.H.; Dacal, E.; et al. Protist enteroparasites in wild boar (Sus scrofa ferus) and black Iberian pig (Sus scrofa domesticus) in southern Spain: A protective effect on hepatitis E acquisition? Parasites Vectors 2020, 13, 281. [CrossRef]

62. Genualdo, V.; Turri, F.; Pizzi, F.; Castiglioni, B.; Marletta, D.; Iannuzzi, A. Sperm nuclei analysis and nuclear organization of a fertile boar-pig hybrid by 2D FISH on both total and motile sperm fractions. Animals 2021, 11, 738. [CrossRef]

63. Petroman, C.; Popescu, G.; Szakal, R.N.; Păunescu, V.; Drăghia, L.P.; Bujancă, G.S.; Chirilă, C.A.; Hădărugă, D.I.; Văduva, L.; Hădărugă, N.G.; et al. Fatty acid profile of lipid fractions of Mangalitza (Sus scrofa domesticus) from northern Romania: A GC-MS-PCA approach. Foods 2021, 10, 242. [CrossRef] [PubMed]

64. Hünermann, K.A. Die Suiden-Reste (Artiodactyla, Mammalia) des Altpleistozäns von Voigtstedt in Thüringen. Paläontologische Abhandlungen Abt. A Paläozoologie 1965, 2, 427-432.

65. Hünermann, K.A. Sus scrofa priscus Goldfuss im Pleistozän von Süßenborn bei Weimar. Paläontologische Abhandlungen Abt. A Paläozoologie 1969, 3, 611-616.

66. Faure, M.; Guérin, C. Le Sus scrofa (Mammalia, Artiodactyla, Suidae) du gisement pléistocène supérieur de Jaurens à Nespouls, Corrèze, France. Nouvelles archives du Muséum d'histoire naturelle de Lyon 1983, 21, 45-63. [CrossRef]

67. Guérin, C.; Faure, M. The wild boar (Sus scrofa priscus) from the post-Villafranchian Lower Pleistocene of Untermaßfeld. In Das Pleistozän von Untermaßfeld bei Meiningen (Thüringen). Teil 1; Monographien des Römisch-Germanischen Zentralmuseums 40, 1; Kahlke, R.-D., Ed.; Römisch-Germanischen Zentralmuseums: Mainz, Germany, 1997; pp. 375-383.

68. Albarella, U.; Dobney, K.; Rowley-Conwy, P. Size and shape of the Eurasian wild boar (Sus scrofa), with a view to the reconstruction of its Holocene history. Environ. Archaeol. 2009, 14, 103-136. [CrossRef]

69. Iannucci, A.; Gasparik, M.; Sardella, R. First report of Sus strozzii (Suidae, Mammalia) from the Early Pleistocene of Hungary (Dunaalmás) and species distinction based on deciduous teeth. Sci. Nat. 2020, 107, 5. [CrossRef]

70. Lister, A.M.; Parfitt, S.A.; Owen, F.J.; Collinge, S.E.; Breda, M. Metric analysis of ungulate mammals in the early Middle Pleistocene of Britain, in relation to taxonomy and biostratigraphy: II: Cervidae, Equidae and Suidae. Quat. Int. 2010, 228, 157-179. [CrossRef]

71. Giuffra, E.J.M.H.; Kijas, J.M.H.; Amarger, V.; Carlborg, Ö.; Jeon, J.T.; Andersson, L. The origin of the domestic pig: Independent domestication and subsequent introgression. Genetics 2000, 154, 1785-1791. [CrossRef]

72. Jing, Y.; Flad, R.K. Pig domestication in ancient China. Antiquity 2002, 76, 724-732. [CrossRef]

73. Larson, G.; Dobney, K.; Albarella, U.; Fang, M.; Matisoo-Smith, E.; Robins, J.; Lowden, S.; Finlayson, H.; Brand, T.; Willerslev, E.; et al. Worldwide phylogeography of wild boar reveals multiple centers of pig domestication. Science 2005, 307, 1618-1621. [CrossRef] [PubMed]

74. Cucchi, T.; Hulme-Beaman, A.; Yuan, J.; Dobney, K. Early Neolithic pig domestication at Jiahu, Henan Province, China: Clues from molar shape analyses using geometric morphometric approaches. J. Archaeol. Sci. 2011, 38, 11-22. [CrossRef]

75. Larson, G.; Burger, J. A population genetics view of animal domestication. Trends Genet. 2013, 29, 197-205. [CrossRef] [PubMed]

76. Price, M.; Hongo, H. The archaeology of pig domestication in Eurasia. J. Archaeol. Res. 2020, 28, 557-615. [CrossRef]

77. Frantz, L.A.; Bradley, D.G.; Larson, G.; Orlando, L. Animal domestication in the era of ancient genomics. Nat. Rev. Genet. 2020, 21, 449-460. [CrossRef] [PubMed] 